\title{
DEVELOPMENT OF COD (CHEMICAL OXYGEN DEMAND) ANALYSIS METHOD IN WASTE WATER USING SPECTRODIRECT
}

\author{
Ade Heri Mulyati ${ }^{\left.a^{*}\right)}$, Leny Heliawati ${ }^{a}$, Sutanto $^{a)}$, Uswatun Hasanah ${ }^{a)}$, \\ Diana Widiastuti $^{a}$, Siti Warnasih $^{a)}$, Yulian Syahputri ${ }^{a}{ }^{\text {) }}$ \\ a) Universitas Pakuan, Bogor, Indonesia \\ Corresponding Author: adeherimulyati@yahoo.com
}

Article history: received 08 August 2020; revised 17 August 2020; accepted 29 August 2020

\begin{abstract}
Increased human activities will cause various problems, one of which is water pollution in water sources because it receives a pollution load that exceeds its carrying capacity. In the context of environmental conservation, the government has set quality standards for liquid waste produced by various industries and other activities in a Decree of the State Minister for the Environment. COD (Chemical Oxygen Demand) is one of the most important parameters in wastewater quality standards. This study aims to validate the COD analysis method which refers to COD Thermoreactor System (LOVIBOND brand) at Pakuan University Service Laboratory, to ensure the validity of COD analysis results at Pakuan University Service Laboratory. Spectrodirect COD analysis method provides results that meet the requirements of accuracy, precision, LOD, and LOQ which is quite good. The results of the Coefficient of Variation give good results with a value of $1.8841 \%$ indicating the accuracy of the analysis method is good. The accuracy parameter also gives good results and meets the requirements with a\% recovery value of $98.70351 \%$. Overall, it can be stated that the spectrodirect analysis method tested is an accurate, precise, simple, and economical method for determining COD levels
\end{abstract}

Keywords: waste water, COD analysis, validation, accuratio, precition

\section{INTRODUCTION}

Water is one of the natural resources which has a very important function for human life, as well as for advancing the general welfare so that it is the basic capital and the main factor of development. The main need for the implementation of good health is the availability of adequate water in terms of quantity and quality, namely meeting the requirements for cleanliness and safety. This water must also be available continuously, attractive and acceptable to the community in order to encourage people to use it [1]. Increased human activities will cause various problems, one of which is water pollution in water sources because it receives a pollution load that exceeds its carrying capacity. Pollution that causes a decrease in water quality can come from point sources and non-point sources. Centralized waste such as industrial waste, livestock business waste, hotel waste, and hospital waste. Meanwhile, the waste is scattered, such as agricultural waste, plantation waste and domestic waste [2].

In the context of environmental conservation, the government has set quality standards for liquid waste produced by various industries and other activities in a Decree of the State Minister for the Environment. According to the concept and its meaning, the water quality standard at the water source, which is abbreviated as the water quality standard, is the level limit allowed for pollutants or substances to be present in water, but the water continues to function according to its designation [3]. Liquid waste quality standard is the limit of permissible levels for pollutant substances or materials to be disposed of from the source of pollution into the water at the water source, so as not to result in exceeding the water quality standard. Ambient air quality standards are the permissible levels for substances or pollutants present in the air, but do not cause disturbance to living things, plants and / or objects [4].

The activity of disposing of liquid waste by industrial estates has the potential to cause environmental pollution, therefore it is necessary to control it [5]. To carry out water pollution control as stipulated in Article 15 of Government Regulation Number 20 of 1990 concerning Water Pollution Control, it is necessary to further stipulate the Liquid Waste Quality Standard. Liquid Waste Quality is the state of liquid waste which is stated by the pollutant discharge, content and load. The maximum discharge is the highest discharge that is still allowed to be discharged into the environment. The maximum level is the highest level which is still allowed to be discharged into the environment. The maximum pollution load is the highest pollution load that is still allowed to be discharged into the environment. Liquid Waste Quality Standards for Industrial Estates that already have a Centralized Waste Processing Unit are as stated in this Decree. For Industrial Estates which do not yet have a Centralized Waste Processing Unit, the Liquid Waste Quality Standard for types of industries shall apply according to the prevailing laws and regulations [6].

The maximum level of each parameter or the maximum waste discharge as mentioned in this Decree can be exceeded as long as the maximum pollution load is not 
exceeded (Article 2). The Governor may stipulate additional parameters beyond the Liquid Waste Quality Standard parameters as meant in this Decree with the approval of the Minister (Article 3). The Liquid Waste Quality Standard is tighter or the same as the Liquid Waste Quality Standard as referred to in this Decree shall remain valid; and the Liquid Waste Quality Standard is looser than the Liquid Waste Quality Standard as referred to in this Decree must be adjusted to the Liquid Waste Quality Standard as referred to in this Decree no later than 1 (one) year after the stipulation of this Decree [7].

The COD measurement method is slightly more complex, because it uses special reflux equipment, use of concentrated acid, heating, and titration (APHA [8]), Umaly and Cuvin [9]. Reflux equipment is needed to avoid reducing the sample water due to heating. In principle, COD measurement is the addition of a number of potassium bichromate $\left(\mathrm{K}_{2} \mathrm{Cr}_{2} \mathrm{O}_{7}\right)$ as an oxidizing agent in the sample (with a known volume) which has been added with concentrated acid and silver sulfate catalyst, then heated for some time. Furthermore, the excess potassium bichromate is measured by titration. Thus the potassium bichromate used for the oxidation of organic matter in the sample can be calculated and the COD value can be determined. The drawback is that inorganic complex compounds in water that can be oxidized are also involved in the reaction (De Santo, [10]). so that in certain cases the COD value may be slightly overestimated to describe the organic matter content. When the new BOD value can be known after the five-day incubation time, the COD value can be immediately known after one or two hours.

Domestic waste is waste originating from bathrooms, latrines, kitchens, washing clothes, washing household appliances, pharmacies, restaurants and so on quantitatively. The waste consists of organic substances in the form of solid or liquid, hazardous and toxic materials (B3), dissolved salts, and bacteria, especially the fecal coli, pathogenic bodies, and parasites [11] The COD analysis method that will be validated in this study refers toCOD Thermoreactor System (LOVIBOND brand) which has never been validated at the Pakuan University Service Laboratory, so this method must be validated to ensure the conformity of its standards to the results of the analysis..

\section{RESEARCH METHODS}

\section{Tools and Materials}

The tools used in this study were COD Thermoreactor RD 125, Measuring flask, Magnetic stirrer, and Spectro Direct.

The materials used in this research are $C O D$ VArio Tube Test Range 0-1500mg / L, NaOH solution $1 \mathrm{~m}, \mathrm{H}_{2} \mathrm{SO}_{4}$ solution $1 \mathrm{~m}, 1 \mathrm{M}$ HCL solution, Nitrification inhibitor B (Allyl Thiourea or ATH)and $\mathrm{KOH}$ solution 45\%

\section{Analysis of Cod in Wastewater Using Spectrodirect}

The research method used includes the manufacture of reagents, stock standard solutions and working standard solutions, optimization of detection parameters on the lovibond brand spectrodirect and validation of the analysis method. The validation of the analysis method carried out is the total validation which refers to the Instruction ManualBO 600 BOD and COD Thermoreactor System(LOVIBOND brand). Validation parameters carried out include selectivity, lower limit of quantification (LLOQ), calibration curve, accuracy, precision, recovery test [12].

\section{Test COD}

Check the $\mathrm{pH}$ of the sample, the optimum $\mathrm{pH}$ for chemical oxidation is $6.0 \sim 7.0$. If the $\mathrm{pH}$ is high, add $\mathrm{HCl}$ (1M) or $\mathrm{H}_{2} \mathrm{SO}_{4}(1 \mathrm{M})$. If the $\mathrm{pH}$ is low, add $\mathrm{NaOH}(1 \mathrm{M})$, mix the water sample well (filtration or homogenization), the sample containing a lot of fiber is homogenized (homogenizer) and the sample containing a lot of algae is filtered with filter paper. A reagent blank containing potassium dichromate and sulfuric acid was prepared (Vario COD Tube Test range $0-1500 \mathrm{mg} / \mathrm{L}$ ), then add $2 \mathrm{ml}$ of deionized water. Prepare a reagent containing potassium dichromate and sulfuric acid (Vario COD Tube Test range 0$1500 \mathrm{mg} / \mathrm{L}$ ), add $2 \mathrm{ml}$ of sample. Each vial was homogenized by shaking it slowly (the vial will become hot when homogenized). Heat the vial in COD Thermoreactor for 120 minutes at a temperature of 150 . After completing the heating process, the vial is placed at room temperature until it is stable, so that it will ${ }^{\circ} \mathrm{C}$ measured the vial is not hot. The vial was measured using a direct spectro with a wavelength of $620 \mathrm{~nm}$ with yield is in $\mathrm{mg} / \mathrm{L}$.

\section{RESULTS AND DISCUSSION}

Based on the analysis of COD levels in sago liquid waste that has been carried out at the Lab Service of Pakuan University, Bogor, the results of the COD examination showed that none of the COD levels exceeded the maximum levels, the results can be seen in the table below.

Table 1. Results of Analysis of COD Levels in Sago Liquid Waste

\begin{tabular}{|c|c|c|c|}
\hline No. & Sample & $\begin{array}{c}\text { Sample Volume } \\
(\mathrm{ml})\end{array}$ & $\begin{array}{l}\text { COD levels } \\
\left(\mathrm{mg} / \mathrm{L} \mathrm{O}_{2}\right)\end{array}$ \\
\hline 1 & Bottle 1 & $2 \mathrm{ml}$ & 147.31 \\
\hline 2 & Bottle 2 & $2 \mathrm{ml}$ & 151.89 \\
\hline 3 & Bottle 3 & $2 \mathrm{ml}$ & 147.35 \\
\hline 4 & Bottle 4 & $2 \mathrm{ml}$ & 150.77 \\
\hline 5 & Bottle 5 & $2 \mathrm{ml}$ & 150.34 \\
\hline 6 & Bottle 6 & $2 \mathrm{ml}$ & 144.37 \\
\hline 7 & Bottle 7 & $2 \mathrm{ml}$ & 145.78 \\
\hline \multicolumn{3}{|c|}{ Average } & 148.2586 \\
\hline
\end{tabular}

\section{Analysis Method Validation}

\section{A. Result of Accuracy Test (Precision)}

The determination of the precision value carried out is a category of repeatability. Accuracy (precision) is determined based on the standard saving value (SD) or the coefficient of variation (KV). Based on the test results, it can be seen that the spectrodirect method used for determining COD levels has a good precision of $1.8841 \%$ with a KV value $\leq 2 \%$. 
Table 2. Results of the COD Accuracy Test on Sago Liquid

Waste
\begin{tabular}{|c|c|c|c|}
\hline No. & Sample & $\begin{array}{c}\text { Sample Volume } \\
(\mathbf{m l})\end{array}$ & $\begin{array}{c}\text { COD levels } \\
(\mathbf{m g} / \text { L O2) }\end{array}$ \\
\hline 1 & Bottle 1 & $2 \mathrm{ml}$ & 147.31 \\
\hline 2 & Bottle 2 & $2 \mathrm{ml}$ & 151.89 \\
\hline 3 & Bottle 3 & $2 \mathrm{ml}$ & 147.35 \\
\hline 4 & Bottle 4 & $2 \mathrm{ml}$ & 150.77 \\
\hline 5 & Bottle 5 & $2 \mathrm{ml}$ & 150.34 \\
\hline 6 & Bottle 6 & $2 \mathrm{ml}$ & 144.37 \\
\hline 7 & Bottle 7 & $2 \mathrm{ml}$ & 145.78 \\
\hline \multicolumn{3}{|c|}{ Average } & $\mathbf{1 4 8 . 2 5 8 6}$ \\
\hline \multicolumn{3}{|c|}{ Standard Deviation } & $\mathbf{2 . 7 9 3 3 4}$ \\
\hline \multicolumn{3}{|c|}{ RSD } & $\mathbf{1 . 8 8 4 1}$ \\
\hline
\end{tabular}

\section{B. Accuracy Test Results}

The accuracy value indicates the accuracy of the analytic method, or the closeness between the measured value and the received value. The accuracy value can be seen from the calculation of $\%$ recovery. The accuracy test is used to show the closeness of the analysis results to the actual analyte content. The result of $\%$ recovery is said to meet the requirements if it shows a percentage value between $80-110 \%$. Based on the results of the calculation, the percentage of recovery was $98.70351 \%$. The percent recovery value which gives a value of $>95 \%$ indicates that the accuracy of the method developed is quite good and the river water sample matrix does not have a significant effect on the measurement results.

Table 3. Data Recovery Test Results

\begin{tabular}{|c|c|c|}
\hline $\begin{array}{c}\text { Actual } \\
\text { concentration } \\
(\mathbf{m g} / \mathbf{L})\end{array}$ & $\begin{array}{c}\text { Measured } \\
\text { Concentration } \\
(\mathbf{m g} / \mathbf{L})\end{array}$ & $\begin{array}{c}\text { Recovery } \\
(\mathbf{\%})\end{array}$ \\
\hline 150,206 & 148.2586 & 98.70351 \\
\hline
\end{tabular}

\section{Detection limit and antitation limit test results (LOD and LOQ)}

The detection limit value states the smallest concentration of analyte in the sample that is still capable of providing quantitative analytical signals. The detection limit is expressed as the concentration of sago waste water which is able to provide a peak height of 3 times the standard deviation, to the peak height of the blank solution ( $\mathrm{S} / \mathrm{N}=$ 3). The result of the calculation shows that the LOD value is $15,980 \mathrm{mg} / \mathrm{L}$ and the LOQ value is $32,082 \mathrm{mg} / \mathrm{L}$

\section{CONCLUSION}

Spectrodirect COD analysis method provides results that meet the requirements of accuracy, precision, LOD, and LOQ which is quite good. The results of the Coefficient of Variation give good results with a value of $1.8841 \%$ indicating the accuracy of the analysis method is good. The accuracy parameter also gives good results and meets the requirements with a\% recovery value of $98.70351 \%$. Overall, it can be stated that the spectrodirect analysis method tested is an accurate, precise, simple, and economical method for determining COD levels.

\section{Acknowledgements}

We want to thank Fakultas Matematika dan Ilmu Pengetahuan Alam Universitas Pakuan for funding this research and to Intan Wulandari for helping research in the laboratory.

\section{REFERENCES}

[1] Asmadi, Khayan, Kasjono H.S. 2011. Teknologi Pengolahan Air Minum. Yogyakarta: Gosyen Publishin g

[2] Asmadi dan Suharno. 2012. Dasar -Dasar Teknologi Pengolahan Air Limbah.Gosyen Publishing : Yogyakarta.

[3] KEP-42 / MENLH / 10/1996. Decree of the State Minister for the Environment Number

[4] KEP-42 / MENLH / 10/1996. Kep. MENLH No. 112 of 2003. Decree of the State Minister of the Environment Number 112 of 2003.

[5] Metcalf \& Eddy, Inc. 1991. Wastewater Engineering: treatment, disposal, reuse. 3rd ed. (Revised by: G. Tchobanoglous and FL Burton).

[6] Kep. MENLH No. 113 of 2003. Decree of the State Minister of the Environment Number 113 of 2003.

[7] Kep. MENLH No. 51 of 2004. Decree of the State Minister for the Environment Number 51 of 2004.

[8] Apha. 1989. Standard methods for the examination of waters and wastewater. 17th ed. American Public Health Association, American Water Works Association, Water Pollution Control Federation. Washington, DC $1467 \mathrm{p}$

[9] McGraw-Hill, Inc. New York, Singapore. 1334 p. Umaly, RC and Ma LA Cuvin. 1988.

[10] De Santo, RS 1978. Concepts of applied ecology. Heidelberg Science Library. Springer-Verlag, New York. 310 p.

[11] Sastrawijaya, 2000, Pencemaran Lingkungan, Rineka Cipta, Jakarta.

[12] Instruction Manual BO 600 BOD and COD Thermoreactor System (LOVIBOND Brand) 